\title{
Antiplatelet and anticoagulation therapy in STEMI patient with acute heart failure and permanent atrial fibrillation on dabigatran
}

\author{
Zoran Jovic ${ }^{1}$, Marijan Spasic ${ }^{1}$, Nemanja Djenic ${ }^{1}$, Boris Dzudovic ${ }^{1}$, Predrag Djuric ${ }^{1}$, \\ Radoslav Romanovic ${ }^{1,2}$, Slobodan Obradovic ${ }^{1,2}$ \\ ${ }^{1}$ Clinic for Cardiology and Urgent Internal Medicine, Military Medical Academy, Belgrade, Serbia, Belgrade, Serbia; \\ ${ }^{2}$ School of Medicine of the Military Medical Academy, University of Defence, Belgrade, Serbia
}

Abstract

Dual antiplatelet therapy (DAPT) present therapy consisting of aspirin and P2Y12, receptor for adenosine 5'-diphosphate (ADP), medicines which protect patients from stent thrombosis and major adverse cardiovascular and cerebrovascular events following the implantation of coronary stents. We report a case of successful primary percutaneous coronary intervention $(\mathrm{pPCl})$ in patient with STEMI and permanent atrial fibrillation who was on oral anticoagulant therapy with direct thrombin inhibitor Dabigatran ( $\operatorname{Pradax}{ }^{\circledR}$ ). Our case showed example of implementation of 2017. ESC guidelines on dual antiplatelet therapy in coronary artery disease in patient with high risk for bleeding. The procedure was successful and patient was discharged from hospital in good condition without any complication.

Key words dual antiplatelet therapy; anticoagulant therapy; atrial fibrillation; myocardial infarction; primary percutaneous coronary intervention.

\section{Introduction}

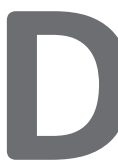

ual antiplatelet therapy (DAPT) present therapy consisting of aspirin and $\mathrm{P}_{2} \mathrm{Y}_{12}$, receptor for adenosine $5^{\prime}$-diphosphate (ADP), medicines which protect patients from stent thrombosis and major adverse cardiovascular and cerebrovascular events following the implantation of coronary stents $^{1,2}$. We report a case of successful primary percutaneous coronary intervention ( $\mathrm{pPCl}$ ) in patient with STE$\mathrm{MI}$ and permanent atrial fibrillation who was on oral anticoagulant therapy with direct thrombin inhibitor Dabigatran (Pradaxa ${ }^{\circ}$ ) and at high risk of bleeding.

Figure 1. ECG on admission at Cath lab

\section{Case Description}

A 74-year-old man with a history of permanent atrial fibrillation, who was on Dabigatran (Pradaxa ${ }^{\circledR}$ ) therapy, received acute chest pain, started at 5 p.m. First medical contact and ECG was done at 6 p.m. in the hospital of

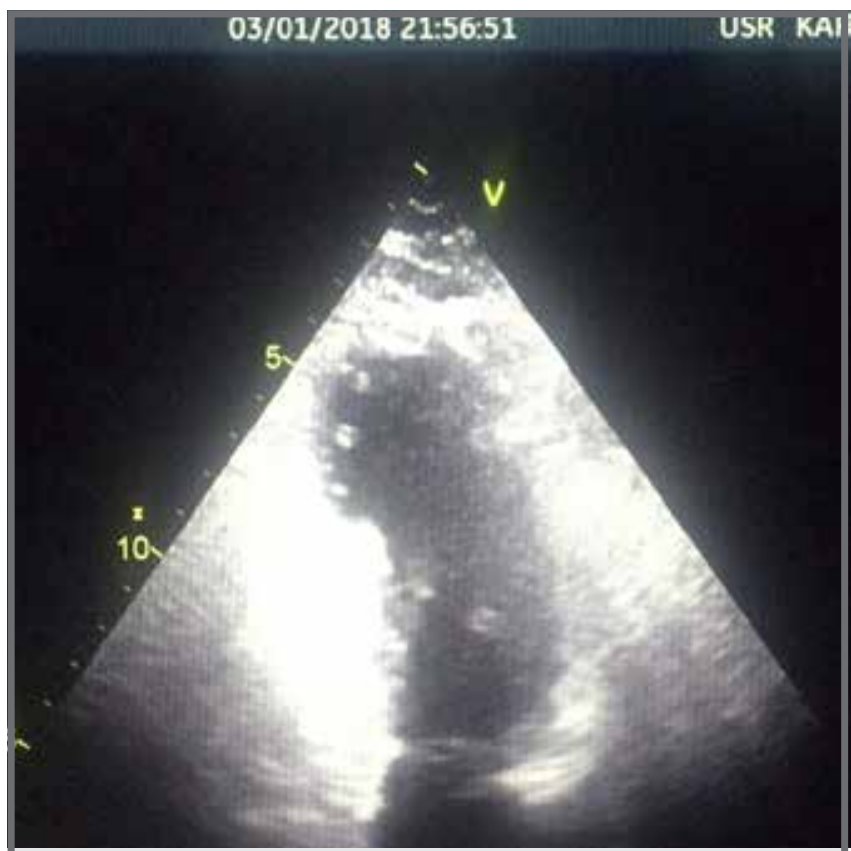

Figure 2. Echocardiography findings at the admission

Corresponding author: Zoran Jović, 1Clinic for Cardiology and Urgent Internal Medicine, Military Medical Academy, Belgrade, Serbia, Belgrade, Serbia; e-mail: zockydr@gmail.com 

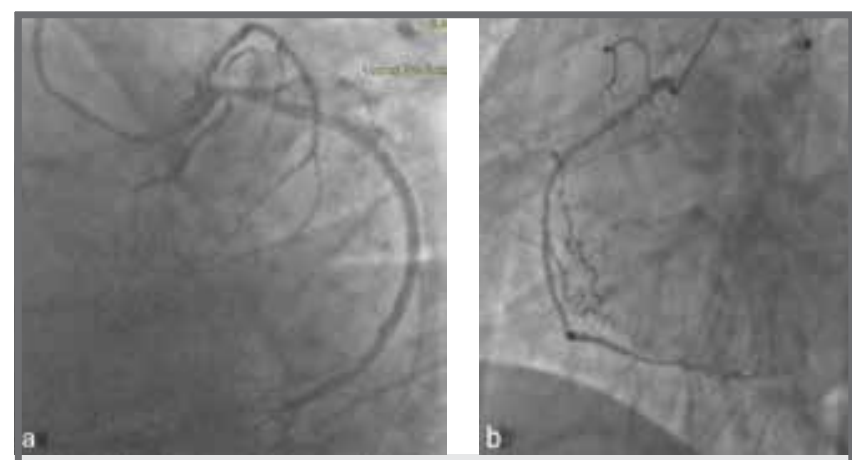

Figure 3. Coronary angiography
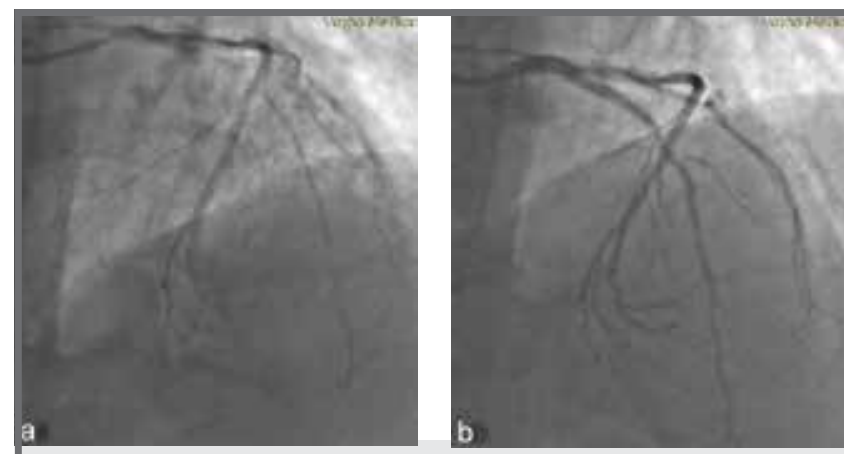

Figure 5. Stent implantation in LAD and final result

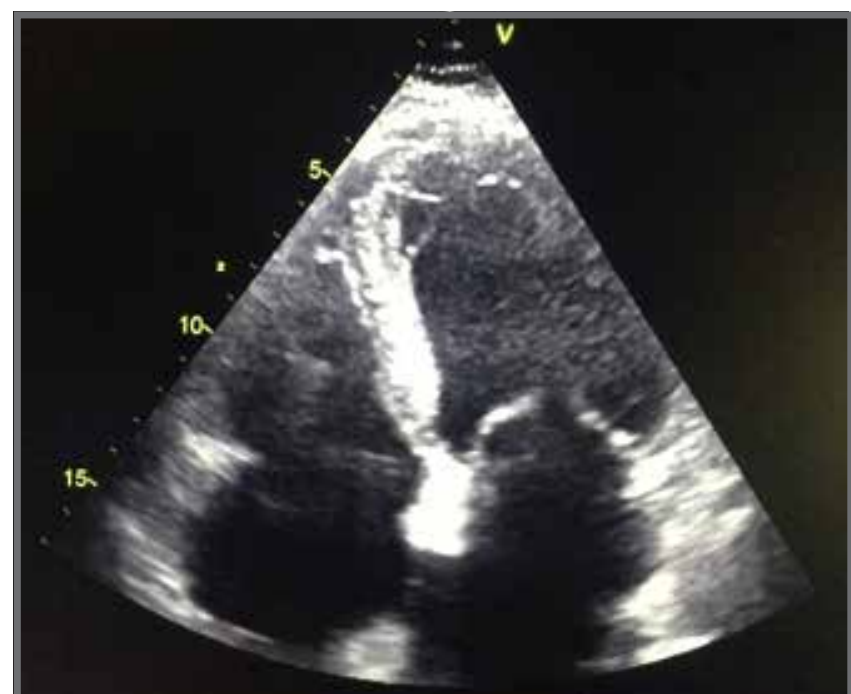

Figure 7. Echocardiography findings after the $\mathrm{pPCl}$

Pozarevac. Immediately afterwards, ventricle fibrillation was registered on ECG, and patient was successfully defibrillated. After that, because acute myocardial infarction with ST elevation was diagnosed, patient received Ticagrelor (Brilique $\left.{ }^{\circ}\right) 180 \mathrm{mg}$ and Aspirin 300 mg, medical team from Pozarevac contacted interventional cardiologist at Military medical academy, and the patient was transferred directly to the Cath lab. The patient arrived to the Military medical academy at 19:30 hours and in Cath lab at 19:45 hours. He took the last pill of Dabigatran (Pradaxa ${ }^{\circledR}$ ) at 9 a.m. ECG revealed atrial fibrillation with heart rate of 102 per minute, wide QRS complex with ST elevation in V1 and V2 and PVC (Figure 1). In laboratory findings on admission CK was 143 and Troponin 10,04 . Echocardiography revealed akinetic wall seg-
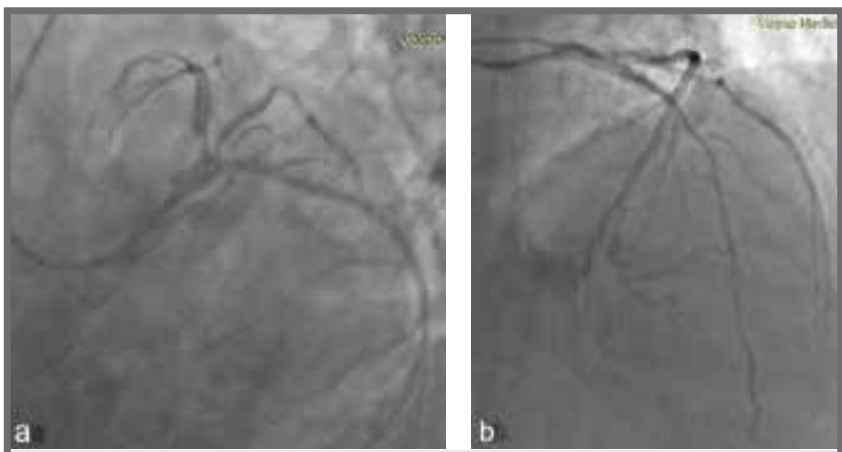

Figure 4. Primary percutaneous coronary intervention on LAD
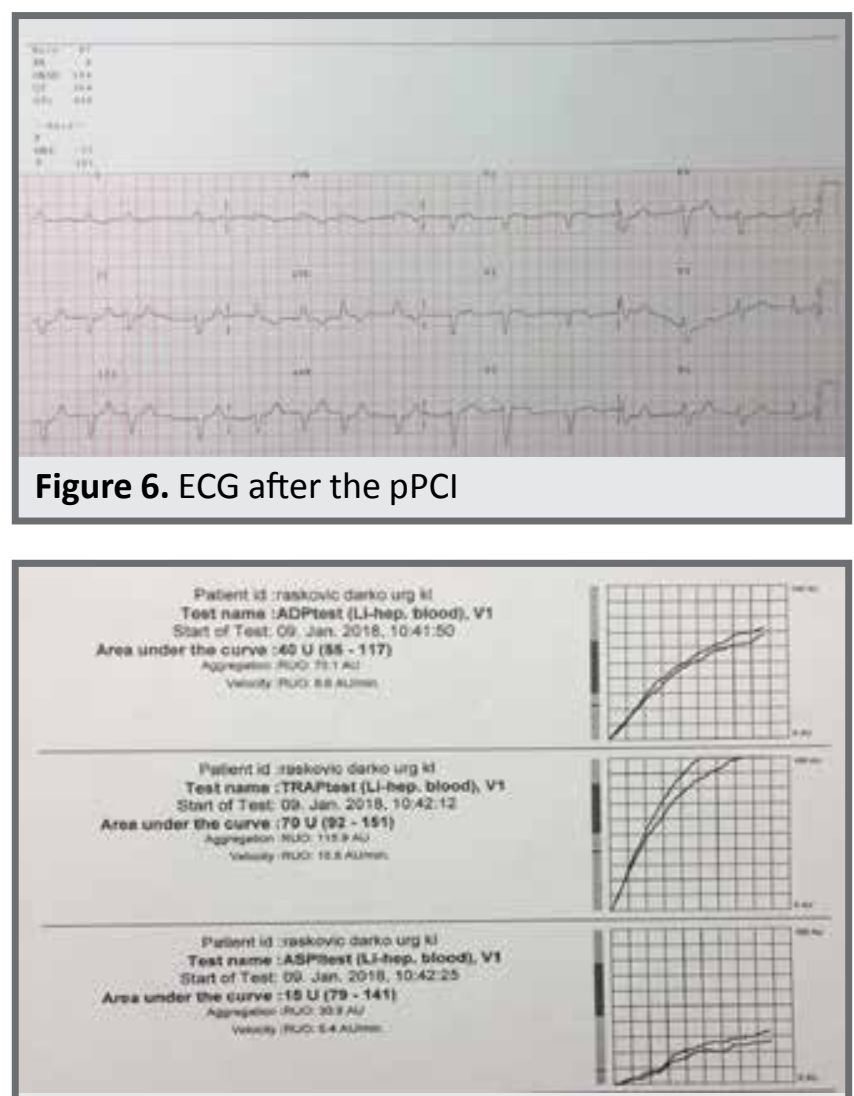

Figure 8. Platelets aggregability results with multiplate test on clopidogrel therapy

ment in distal part of septum, apex and distal part of anterior wall (Figure 2). Coronary angiography was done and showed occluded left anterior descending artery (Figure $3 \mathrm{a}$ and $3 \mathrm{~b}$ ). The procedure was continued and the primary $\mathrm{PCl}$ (Figure $4 \mathrm{a}$ and $4 \mathrm{~b}$ ) was made with implantation of two stents, one bare metal and one drug eluting stent (Figure $5 \mathrm{a}$ and $5 \mathrm{~b}$ ). After the procedure ECG showed complete resolution of ST segment elevation (Figure 6). Echocardiography was done after the procedure and no changes were found regarding the results on the beginning (Figure 7). Control laboratory testing showed CK 2899, CK-MB 291, LDH 549 and BNP 777.3. The patient was in acute heart failure. We administrated heparin $5000 \mathrm{U}$.I. on every 6 hours with monitoring of aPTT, ticagrelor $90 \mathrm{mg}$ twice a day, aspirin $100 \mathrm{mg}$ once a day, zofenopril, furosemide, bisoprolol and rosuvastatin. At the fifth day, we switched from ticagrelor to 
klopidogrel with 600 mg per once, 24 hours after the last dose of ticagrelor and also started with rivaroxaban (Xarelto ${ }^{\circledR}$ ) $15 \mathrm{mg}$ per day. We controlled platelets aggregability on discharge (Figure 8), with multiplate test, and continued with clopidogrel and rivaroxaban therapy.

\section{Discussion}

DAPT is very important therapy in patients who's going on $\mathrm{pPCl}$ with or without stent implantation. In atrial fibrillation patients, the risk for bleeding is much higher because of anticoagulation therapy that patients already received.

\section{Conclusion}

Our case showed example of implementation of 2017 ESC guidelines on dual antiplatelet therapy in coronary artery disease in patient with high risk for bleeding. The procedure was successful and patient was discharged from hospital in good condition without any complication.

Commentary according to DAPT guidelines. A 76 year old male was admitted two hours after the onset of chest pain for the $\mathrm{PCl}$ under the clinical presentation of extensive anterior STEMI and with the clinical signs of acute heart failure (Killip 2 class). Patient had the history of permanent atrial fibrillation and he used dabigatran $150 \mathrm{mg}$ bid for the last four months. The last dose was taken 10 hours before admission to the $\mathrm{PCl}$ center. Patient also recieved loading dose of ticagrelor and aspirin in the local hospital and transferred to the $\mathrm{PCl}$ center immediately. He did not have previous chest discomfort. The total ischemic time from the chest onset to the catheterization room was around 3 hours. There are some important points regarding the treatment of this patients:

1. Radial approach is recommended by the new STE$\mathrm{MI}$ guidelines and it was particularly important for the patient on oral anticoagulation therapy.

2. Since patient had extensive STEMI and signs of acute heart failure at admission we switched him from the oral anticoagulant therapy to safer heparin therapy for the next few days because we expected worsening of the glomerular filtration rate.

3. For the first 5 days we continued ticagrelor therapy because this is the most vulnerable period for stent thrombosis.
4. However patient need DAPT and anticoagulation therapy and after STEMI it is recommended for at least 6 months. Because of the higher incidence of non-CABG major bleeding with ticagrelor compare to clopidogrel we switched the patient to clopidogrel at the fifth day after admission with the loading dose of $600 \mathrm{mg}$ of clopidogrel instead the next dose of ticagrelor. The necessity for using oral anticoagulation is probable the right indication for the switching from more potent ticagrelor to less potent clopidogrel. We introduced clopidogrel at the fifth day from the STEMI avoiding possible acute resistance to clopidogrel which is very often temporary present during the ACS and the ticagrelor covered the most vulnerable time for stent thrombosis.

5. At the same day we stopped heparin and introduced rivaroxaban at the dose of $15 \mathrm{mg}$. Patient indeed had GFR between $50-60 \mathrm{ml} / \mathrm{min}$ during the hospital stay and we choose this dose because we planned at least one month triple therapy with clopidogrel and aspirin. Patient had CHA2DS2VASc score 5 and he obviously need oral anticoagulation therapy. Since patient had high ischemic risk (DAPT score was 3 in spite of the 75 years which takes 2 negative points) and also high bleeding risk (PRECISE DAPT score was 27) we decide to give him triple therapy for one month and to proceed with clopidogrel and rivaroxaban (15 $\mathrm{mg}$ ) for the next 6 months, and after that we planned monotherapy with rivaroxaban very probably 20 mg per day.

6. DAPT score and PRECISE DAPT score are unfortunately not well suited for such severe STEMI patient because they derived from the cohorts with small number of STEMI patients especially STEMI patients on oral anticoagulant therapy. .

\section{References}

1. Valgimigli M, Bueno H, Byrne RA, et al. 2017 ESC focused update on dual antiplatelet therapy in coronary artery disease developed in collaboration with EACTS. The Task Force for dual antiplatelet therapy in coronary artery disease of the European Society of Cardiology (ESC) and of the European Association for Cardio-Thoracic Surgery (EACTS). Eur Heart J 2018; 39:213-254.

2. Collet JP, Roffi M, Robert A, et al. Case-based implementation of the 2017 ESC Focused Update on Dual Antiplatelet Therapy in Coronary Artery Disease. The Task Force for the Management of Dual Antiplatelet Therapy in Coronary Artery Disease of the European Society of Cardiology (ESC) and of the European Association for Cardio-Thoracic Surgery (EACTS). Eur Heart J 2018; 39: e1-e33. 


\section{Sažetak}

\section{Antitrombocitna i antikoagulantna terapija kod bolesnika sa STEMI-jem i akutnom srčanom} insuficijencijom koji je na dabigatranu zbog permanentne atrijalne fibrilacije

Zoran Jovic ${ }^{1}$, Marijan Spasic ${ }^{1}$, Nemanja Djenic ${ }^{1}$, Boris Dzudovic ${ }^{1}$, Predrag Djuric ${ }^{1}$, Radoslav Romanovic ${ }^{1,2}$, Slobodan Obradovic ${ }^{1,2}$

${ }^{1}$ Klinika za kardiologiju i urgentnu internu medicinu, Vojnomedicinska akademija, Beograd, Srbija, ${ }^{2}$ Medicinski fakultet, Univerzitet odbrane, Beograd, Srbija

Aorte stenoza je najčešća bolest valvula koja zahteva zamenu bilo operativnim lečenjem bilo transkateter interDvojna antitrombocitna terapija (DAPT) predstavlja terapiju koja se sastoji od aspirina i P2Y12, receptora za adenozin 5'-difosfat (ADP), lekova koji štite pacijente od tromboze stenta i glavnih neželjenih kardiovaskularnih i cerebrovaskularnih događaja nakon implantacije koronarnih stentova. Prikazujemo slučaj uspešne primarne perkutane koronarne intervencije ( $P P C I$ ) kod pacijenta sa infarktom miokarda sa ST elevacijom i permanentnom atrijalnom fibrilacijom, koji je bilo na oralnoj antikoagulantnoj terapiji sa direktnim inhibitorom trombina Dabigatranom (Pradaxa ${ }^{\circledR}$ ). Naš slučaj je pokazao primenu 2017. ESC smernica za dvojnu antitrombocitnu terapiju u koronarnoj bolesti kod pacijenata sa visokim rizikom za krvarenje. Procedura je bila uspešna i pacijent je otpušten iz bolnice $u$ dobrom stanju bez ikakvih komplikacija.

Ključne reči: dvojna antitrombocitna terapija; antikoagulantna terapija, atrijalna fibrilacija; infarkt miokarda; primarna perkutana koronarna intervencija. 